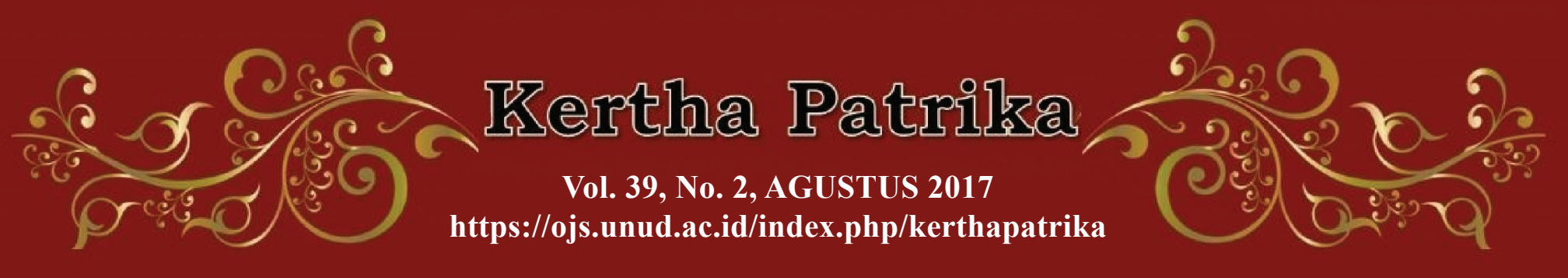

\title{
TANGGUNG JAWAB PRESIDEN ATAS KEBIJAKAN MENTERI \\ YANG MENIMBULKAN KORUPSI \\ BERDASARKAN SISTEM PRESIDENSIAL DAN TEORI KEWENANGAN
}

Oleh :

\section{Josef Mario Monterio ${ }^{1}$}

Fakultas Hukum Universitas Nusa Cendana Kupang

\begin{abstract}
Abstrak
Kajian yang bersifat yuridis normatif ini dimaksudkan untuk menjelaskan dapatkah Presiden bertanggung jawab atas kebijakan menterinya yang menimbulkan korupsi. Berdasarkan sistem pemerintahan presidensial, Presiden bertanggung jawab secara moral kepada rakyat apabila menteri mengeluarkan kebijakan yang melanggar nilai-nilai moral. Selanjutnya Presiden bertanggung jawab secara politik kepada rakyat: apabila menteri mengeluarkan kebijakan yang melanggar peraturan perundang-undangan, dan apabila kebijakan menteri telah merugikan keuangan negara. Berdasarkan teori kewenangan, Presiden adalah pemberi mandat dan menteri sebagai mandataris sehingga berlaku asas vicarious liability yaitu atasanlah yang bertanggung jawab, artinya Presiden bertanggung jawab secara hukum atas kebijakan menteri yang menimbulkan korupsi.
\end{abstract}

Kata Kunci: Sistem Presidensial, Mandat, Kebijakan, Korupsi.

\section{Abstract}

This normative juridical study is intended to explain whether the President is responsible for his corrupt ministerial policies. Under the presidential government system, the President is morally responsible to the people when the minister issues policies that violate moral values. Furthermore, the President is politically responsible to the people: if the minister issues a policy that violates the laws and regulations, and if the minister's policy has harmed the state's finances. Based on the theory of authority, the President as the official who delivers the mandate and minister as the receiver of the mandate, so that the validity of the principle of vicarious liability is the responsible boss, meaning that the President is legally responsible for the ministerial policy that leads to corruption.

Keywords: Presidential System, Mandate, Policy, Corruption.

DOI: https:doi.org/10.24843/KP.2017.v39.i02.p01

Copyright (C) 2017 Jurnal Kertha Patrika.

\section{Pendahuluan}

Sistem pemerintahan Republik Indonesia sebagaimana yang dianut oleh Undang-Undang Dasar Negara Republik Indonesia Tahun 1945 (UUD NRI Tahun 1945) adalah sistem pemerintahan presidensial. Berdasarkan sistem pemerintahan presidensial, Presiden adalah jabatan yang dilekati tugas dan kewenangan untuk menjalankan urusan pemerintahan, di samping urusan

1 Josef Mario Monterio adalah Dosen Fakultas Hukum Universitas Nusa Cendana Kupang, korespondensi dengan penulis melalui email : josefmonteiro@ymail.com 
KERTHA PATRIKA

Volume 39, Nomor 2, Agustus 2017

kenegaraan. ${ }^{2}$ Ketentuan Pasal 4 ayat (1) UUD NRI Tahun 1945 menyebutkan: "Presiden Republik Indonesia memegang kekuasaan pemerintahan menurut Undang-Undang Dasar". Oleh karenanya, ketika akan menjalankan urusan pemerintahan, Presiden membutuhkan kewenangan. Hal ini dapat dipahami mengingat keabsahan tindakan hukum pemerintah tergantung ada atau tidaknya kewenangan. Dengan kata lain, dalam suatu negara hukum, ${ }^{3}$ pemerintah hanya dapat melakukan perbuatan hukum jika ia memiliki kewenangan.

Sistem pemerintahan Republik Indonesia sebagaimana yang dianut oleh Undang-Undang Dasar Negara Republik Indonesia Tahun 1945 (UUD NRI Tahun 1945) adalah sistem pemerintahan presidensial. Berdasarkan sistem pemerintahan presidensial, Presiden adalah jabatan yang dilekati tugas dan kewenangan untuk menjalankan urusan pemerintahan, di samping urusan kenegaraan. Ketentuan Pasal 4 ayat (1) UUD NRI Tahun 1945 menyebutkan: "Presiden Republik Indonesia memegang kekuasaan pemerintahan menurut Undang-Undang Dasar”. Oleh karenanya, ketika akan menjalankan urusan pemerintahan, Presiden membutuhkan kewenangan. Hal ini dapat dipahami mengingat keabsahan tindakan hukum pemerintah tergantung ada atau tidaknya kewenangan. Dengan kata lain, dalam suatu negara hukum, pemerintah hanya dapat melakukan perbuatan hukum jika ia memiliki kewenangan.

Pada hakikatnya terdapat 2 (dua) jenis kewenangan, yaitu: kewenangan terikat (gebonden bevoegheid) dan kewenangan bebas (verijebevogdheid). Kewenangan terikat bersumber dari undang-undang atau peraturan perundang-undangan yang berlaku, yang diperoleh baik secara atribusi, delegasi maupun mandat, ${ }^{4}$ sedangkan kewenangan bebas bersumber pada freies ermessen atau yang melekat pada pemerintah sebagai administrasi negara dalam negara hukum modern. Freies ermessen adalah suatu kebebasan yang diberikan kepada alat administrasi, yaitu kebebasan yang pada asasnya memperkenankan alat administrasi negara mengutamakan keefektifan tercapainya suatu tujuan (doelmatigheid) daripada berpegang teguh kepada ketentuan hukum, ${ }^{5}$ atau sebagai salah satu sarana yang memberikan ruang bergerak bagi pejabat atau badan-badan adminstrasi negara untuk melakukan tindakan tanpa harus terikat sepenuhnya pada undangundang. ${ }^{6}$ Freies ermessen merupakan kebebasan yang diberikan kepada tata usaha negara dalam rangka penyelenggaraan pemerintahan, sejalan dengan meningkatnya tuntutan pelayanan

2 Tugas dan kewenangan Presiden di bidang pemerintahan dan kenegaraan ini terkait dengan kedudukan Presiden Republik Indonesia, yakni sebagai kepala pemerintahan dan juga sebagai kepala Negara.

3 Ketentuan Pasal 1 ayat (3) UUD NRI Tahun 1945 menyebutkan bahwa,"Negara Indonesia adalah negara hukum".

4 Atribusi (atributie) adalah pemberian wewenang pemerintahan oleh pembuat undang-undang kepada organ pemerintahan, delegasi (delegatie) adalah pelimpahan wewenang premerintahan dari satu organ pemerintahan kepada organ pemerintahan lainnya, sedangkan mandat (mandaat) adalah pelimpahan wewenang kepada bawahan dan dimaksudkan untuk membuat keputusan untuk dan atas nama pejabat tata usaha negara yang memberi mandat. H.D. van Wijk/Willem Konjnenbelt, 1995, Hoofdstukken van Administratief Recht, s'gravenhage, h. 129.

5 M.Nata Saputra, 1988, Hukum Administrasi Negara, Jakarta: Penerbit Rajawali, h. 15.

${ }^{6}$ Marcus Lukman, 1996, "Eksistensi Peraturan Kebijaksanaan dalam Bidang Perencanaan dan Pelaksanaan Rencana Pembangunan di Daerah serta Dampaknya terhadap Pembangunan Materi Hukum Tertulis Nasional”, Disertasi, Universitas Padjajaran, Bandung, h. 205. 
publik yang harus diberikan tata usaha negara terhadap kehidupan sosial ekonomi para warga yang kian komplek. ${ }^{7}$

Sehubungan dengan kewenangan Presiden menjalankan pemerintahan, dalam konstitusi dinyatakan bahwa Presiden dibantu oleh menteri negara. Ketentuan Pasal 17 ayat (1) dan (2) UUD NRI Tahun 1945 menyebutkan: (1) Presiden dibantu oleh menteri-menteri negara; (2) Menteri-menteri itu diangkat dan diberhentikan oleh Presiden. Rumusan ini merupakan hasil amandemen pertama terhadap UUD NRI Tahun 1945 yang dilakukan oleh Majelis Permusyawaratan Rakyat. Bila rumusan tersebut dibandingkan dengan rumusan sebelum UUD NRI Tahun 1945 diamandemen, maka Pasal 17 ayat (1) berbunyi: "Presiden dibantu oleh menteri-menteri negara." Pasal 17 ayat (2) dijumpai rumusan: "Menteri-menteri itu diangkat dan diberhentikan oleh Presiden" dan Pasal 17 ayat (3) menyatakan: "Menteri-menteri itu memimpin departemen pemerintahan."

Berdasarkan rumusan dalam ketentuan UUD NRI Tahun 1945 sebelum dan setelah amandemen, nampaknya hanya diatur soal kedudukan dan fungsi menteri sebagai pembantu Presiden yang memimpin departemen atau kementerian, sedangkan mengenai kewenangan menteri dalam mengeluarkan kebijakan, UUD NRI Tahun 1945 tidak mengaturnya secara tegas, apakah menteri berwenang mengeluarkan kebijakan untuk dan atas nama Presiden, ataukah menteri berwenang secara mandiri mengeluarkan kebijakannya. Selain itu, timbul persoalan hukum sehubungan dengan keadaan apabila menteri mengeluarkan kebijakan yang menimbulkan korupsi, dapatkah Presiden bertanggung jawab atas kebijakan menterinya. Terhadap keadaan tersebut telah menimbulkan "grey area"dalam UUD NRI Tahun 1945.

Berdasarkan latar belakang tersebut diatas, adapun rumusan permasalahan yang kemudian akan dibahas dalam tulisan ini meliputi:

1. Berdasarkan sistem pemerintahan presidensial dapatkah presiden bertanggung jawab atas kebijakan menteri yang menimbulkan korupsi?

2. Berdasarkan teori kewenangan dapatkah presiden bertanggung jawab atas kebijakan menteri yang menimbulkan korupsi?

\section{HASIL DAN PEMBAHASAN}

\subsection{Sistem Pemerintahan Presidensial}

Pada dasarnya dalam sistem pemerintahan presidensial, kekuasaan presiden tidak hanya sebagai kepala pemerintahan (chief of executive), tetapi juga sebagai kepala negara (chief of state). Itulah sebabnya rentang kekuasaan presiden tidak hanya menyentuh wilayah kekuasaan

7 Laica Marzuki, 26-31 Agustus 1996, "Peraturan Kebijaksanaan (Beleidsregel) Hakikat serta Fungsinya Selaku Sarana Hukum Pemerintahan”, Makalah pada Penataran Nasional Hukum Acara dan Hukum Administrasi Negara, Fakultas Hukum Universitas Hasanudin, Ujung Pandang, h.7. 
eksekutif, tetapi juga merambah pada fungsi legislasi dan yudikatif. ${ }^{8}$ Dengan rentang kekuasaan presiden yang begitu luas, jika dalam sistem pemerintahan parlementer objek utama yang diperebutkan adalah parlemen, maka dalam sistem pemerintahan presidensial objek utama yang diperebutkan adalalah presiden. Sekalipun dalam sistem pemerintahan presidensial tidak satu pun lembaga negara yang menjadi fokus kekuasaan, ${ }^{9}$ peran dan karakter individu presiden lebih menonjol dibandingkan dengan peran kelompok, organisasi, atau partai politik yang ada dalam negara. Karena itu, mayoritas pendapat ahli dalam menguraikan karakter sistem presidensial cenderung memperhadapkan (vis a vis) posisi presiden dengan lembaga legislatif. ${ }^{10}$

Selanjutnya sistem pemerintahan presidensial mempunyai karateristik sebagai berikut:

\section{The president is both nominal and political head of state;}

2. The president is not elected by the legislature, but is directly elected by the total electorate. (There is an electoral college in the United States, but it is of political significance only in that each states votes as unit and hence the system tends to disadvantage small parties);

3. The President is not part of the legislature, and he cannot be from office by the legislature except through the legal process of impeachment;

4. The president cannot dissolve the legislature and call a general election. Ussualy the president and the legislature are elected for mixed terms. ${ }^{11}$

Pendapat senada juga dikemukan oleh Jimly Asshiddiqie yang menguraikan sistem pemerintahan presidensial (murni) sebagai berikut:

1. Presiden memegang kekuasaan pemerintahan eksekutif tunggal;

2. Dalam kedudukan sebagai pemegang kekuasaan pemerintahan negara itu terkandung pula status kepala negara (head of state), sehingga kedudukan kepala negara (head of state) dan kepala pemerintahan eksekutif (head of government) menyatu secara tidak terpisahkan dalam jabatan presiden;

3. Presiden tidak diangkat atau dipilih oleh lembaga perwakilan rakyat;

4. Presiden tidak bertanggung jawab kepada lembaga perwakilan rakyat, sehingga tidak dapat dijatuhkan oleh parlemen karena alasan politik;

5. Presiden memangku jabatannya selama kurun waktu yang tetap (fixed term), misalnya di Amerika Serikat ditentukan untuk waktu empat tahun, di Indonesia lima tahun dan sesudahnya dapat dipilih lagi untuk satu periode berikutnya;

6. Presiden hanya dapat diberhentikan dari jabatannya melalui prosedur yang dikenal dengan

\footnotetext{
8 Denny Indrayana, 2007, Amandemen UUD 1945: Antara Mitos dan Pembongkaran, Jakarta: Penerbit Mizan, h. 3.

9 Douglas V. Verney dalam Saldi Isra, 2010, Pergeseran Fungsi Legislasi, Jakarta: Penerbit Raja Grafindo, h. 38.

10 Ibid., h. 38.

11 Allan R.Ball \& B. Guy Peters dalam Saldi Isra, loc.cit.
} 
"impeachment" karena alasan pelanggaran hukum sebagaimana ditentukan dalam undangundang dasar. ${ }^{12}$

\subsection{Tanggung Jawab Presiden atas Kebijakan Menteri Berdasarkan Sistem Presidensial}

Dalam ajaran hukum, negara adalah organisasi jabatan (ambtenarorganisatie). ${ }^{13}$ Jabatan adalah suatu lembaga dengan lingkup pekerjaan sendiri yang dibentuk untuk waktu lama dan kepadanya diberikan tugas dan wewenang. ${ }^{14}$ Dalam menjalankan tugas dan kewenangannya, jabatan ini dijalankan melalui wakil (vertegenwoordiger), yakni pejabat (ambtsdrager). Jabatan itu bersifat tetap, sementara pemegang jabatan dapat berganti-ganti. Tugas dan kewenangan itu dilekatkan pada jabatan, bukan pejabat. Oleh karena itu, tugas dan kewenangan itu tetap ada sepanjang jabatan yang bersangkutan masih ada, meskipun pejabatnya sudah berganti. Diantara jabatan yang ada dalam suatu negara adalah jabatan pemerintahan, yang dilekati tugas dan kewenangan untuk menjalankan urusan pemerintahan.

Sistem pemerintahan presidensial yang dianut oleh UUD NRI Tahun 1945 menegaskan menteri adalah pembantu presiden. Oleh karenanya menteri diserahi tugas dan kewenangan menjalankan pemerintahan sesuai lingkup kementeriannya masing-masing. Jika ditinjau dari aspek kedudukan, menteri adalah pembantu presiden yang diangkat dan diberhentikan oleh Presiden, sehingga konstruksi ini merupakan kabinet presidensial. Karateristik kabinet yang bersistem presidensial adalah Presiden merupakan penanggungjawab tertinggi atas kebijakan yang dikeluarkan oleh menteri-menterinya. Pertanggungjawaban presiden yang dimaksud yaitu:

1. Pertanggunjawaban Presiden secara moral

Didasarkan atas pemikiran bahwa setiap orang memiliki naluri untuk membedakan antara yang baik dan yang buruk. Moral dalam bahasa Latin, yaitu mos atau mores yang berarti kelakukan, watak, akhlak, dan cara hidup. Hal ini tidak lain mengacu pada baik buruknya manusia, dan menuntun bagaimana seharusnya manusia hidup, atau apa yang boleh dan apa yang tidak boleh dilakukan.

Sehubungan dengan hal tersebut, UUD NRI Tahun 1945 merupakan dokumen tertulis, tetapi mesti dibaca secara khas, tidak seperti membaca teks biasa, melainkan membacanya secara bermakna, yang oleh Ronal Dworkin disebut sebagai "moral reading"15. Arti moral reading adalah membaca moral di belakang konstitusi tertulis. Oleh karena itu kita membaca UUD NRI Tahun 1945 sebagai dokumen hukum yang mengadung nilai moral bagi segenap rakyat Indonesia. Oleh karena itu ketika membaca ketentuan Pasal 4 jo Pasal 17

12 Jimly Asshiddiqie, 2007, Pokok-Pokok Hukum Tata Negara Pasca Reformasi, Jakarta: Penerbit Bhuana Ilmu Populer, h. 335 .

13 Logemann, 1954, Over de Theorie van een Stellig Staatsrecht, Jakarta: Penerbit Seksama, h. 88.

14 N.E. Algra \& H.C.J.G. Janssen, 1974, Rechtsingang, een Orientatie in het Recht, H.D.Tjeenk Willink bv: Groningen, h. 175 .

15 Ronal Dworkin, 1996, Freedom's Law, The Moral Reading of American Constitution, Mass: Harvard University, Cambridge, h.17. 
UUD NRI Tahun 1945, terdapat nilai moral penting yang ingin diwujudkan, yaitu setiap menteri harus menjiwai pelaksanaan pekerjaannya dengan nilai empati, dedikasi, komitmen, kejujuran, kebenaran, keberanian, dan lain sebagainya. Hasil pekerjaan seorang menteri tidak hanya diukur dari segi kuantitas, melainkan juga kualitas karena didasari oleh "moral description"16. Dengan demikian, konstitusi sebagai hukum dasar tertinggi yang sarat akan nilai moral mengamanatkan bahwa Presiden sebagai penyelenggara pemerintahan tertinggi wajib menjunjung tinggi moralitas bangsa, sehingga apabila ada kebijakan menteri sebagai pembantunya yang melanggar hukum seperti korupsi, maka Presiden secara moral bertanggung jawab kepada rakyat.

Herman Finer mengartikan pertanggunjawaban moral (moral responsibility) suatu pemerintahan sebagai penerimaan patokan-patokan perilaku yang dipaksakan kepada diri sendiri oleh seorang politisi atau pejabat, suatu pengaturan diri sendiri yang tumbuh dari dalam hati nurani bagi tingkah lakunya. Pada akhirnya patokan-patokan perilaku tadi hanya dipahami atau ditafsirkan sendiri oleh penguasa, dan bukannya oleh mereka yang membebani pertanggungjawaban. ${ }^{17}$

2. Pertanggungjawaban Presiden secara politik

Pada hakikatnya tanggung jawab presiden secara politik atas kebijakan menteri didasarkan pada pertimbangan bahwa jabatan menteri bukanlah jabatan biasa seperti dalam sistem kepegawaian negara, melainkan jabatan negara yang pengangkatannya bersifat politik. Akibatnya kebijakan apapun yang dikeluarkan menteri tentu berdampak secara politik terhadap kedudukan presiden. Oleh karena itu, membaca makna Pasal 4 jo Pasal 17 UUD NRI Tahun 1945 dan sesuai pula dengan asas responsible government, maka secara tersirat dapat dikatakan bahwa Presidenlah yang bertanggung jawab secara politik atas kebijakan yang dikeluarkan oleh menteri-menterinya, termasuk kebijakan menteri yang menimbulkan korupsi.

Pertanggungjawaban Presiden secara politik memiliki ciri sebagai berikut:

a. Presiden adalah pelaksana peraturan perundang-undangan. Dari segi pemikiran falsafah konstitusi dapat dikatakan bahwa Presiden adalah pelaksana tertinggi peraturan perundang-undangan. Konstruksi ini mengartikan bahwa jika para menterinya mengeluarkan kebijakan yang melanggar peraturan perundang-undangan, maka secara politik Presidenlah yang bertanggung jawab kepada rakyat. Mekanismenya melalui pemilihan umum karena melalui pemilu, presiden akan "dihakimi” rakyat. Dalam hal ini rakyat akan menilai berhasil atau tidaknya Presiden dari hasil kinerja para menterinya, yaitu apakah kebijakannya bertentangan dengan peraturan perundang-undangan ataukah sebaliknya.

\footnotetext{
${ }^{16}$ Satjipto Rahardjo, 2009, Negara Hukum yang Membahagiakan Rakyatnya, Yogyakarta: Penerbit Genta Publishing, h. 93.

${ }^{17}$ Herman Finer dalam Philips A Kana, 2006, "Para Menteri Tidak Bisa Lepas Tanggung Jawab", Makalah, Universitas Krisna Dwipayana, h. 5.
} 
b. Tanggung jawab presiden secara politik atas pengelolaan keuangan negara. ${ }^{18}$ Sebagaimana ditegaskan dalam Pasal 23E UUD Negara Republik Indonesia Tahun 1945 ayat (1) bahwa untuk memeriksa pengelolaan dan tanggung jawab tentang keuangan negara diadakan satu Badan Pemeriksa Keuangan (BPK) yang bebas dan mandiri. Selanjutnya pada ayat (2) disebutkan bahwa hasil pemeriksaan keuangan negara diserahkan kepada Dewan Perwakilan Rakyat (DPR), Dewan Perwakilan Daerah (DPD), dan Dewan Perwakilan Rakyat Daerah (DPRD) sesuai kewenangannya. Berdasarkan ketentuan tersebut, apabila hasil pemeriksaan BPK terhadap kementerian telah ditemukan adanya kebijakan menteri yang merugikan keuangan negara berupa korupsi, maka presiden secara politik bertanggung jawab kepada rakyat melalui DPR dan DPR.

\subsubsection{Tanggung Jawab Presiden Atas Kebijakan Menteri Berdasarkan Teori Kewenangan}

Berdasarkan sistem ketatanegaraan Republik Indonesia, hubungan Presiden dan Menteri-Menteri adalah hubungan atasan dan bawahan, karenanya menteri merupakan pemberi dukungan staf dan pelayanan administrasi kepada Presiden. Jika ketentuan Pasal 4 dan Pasal 17 UUD NRI Tahun 1945 dihubungkan dengan teori kewenangan dalam hukum administrasi, maka Presiden adalah mandan (pemberi mandat) dan Menteri-Menteri sebagai mandataris.

Menurut kamus hukum Belanda-Indonesia, kata mandaat secara umum artinya opdracht, perintah; mempercayakan (toever-trouwen); dan memerintahkan (bevelen). ${ }^{19}$ Pertanggungjawaban mandat bersumber dari persoalan "wewenang", artinya karena wewenang tetap berada pada mandans, sedangkan mandataris hanya dilimpahi wewenang untuk dan atas nama mandans. Oleh karena itu, pertanggungjawaban yuridis tetap pada mandan dan mandataris hanya sebagai pelaksana belaka dari mandan. Apabila mandataris mengambil suatu keputusan maka keputusan itu berlaku sebagai keputusan dari mandans, meskipun keputusan itu ditandatangani oleh mandataris, kecuali hal tersebut jelas-jelas dilarang atau ditentukan lain oleh peraturan perundang-undangan atau bertentangan dengan sifat wewenangnya.

Beberapa kasus dapat diangkat sebagai contoh, yaitu dimulai pada masa pemerintahan Presiden B.J Habibie sehubungan dengan kasus Ir. Akbar Tanjung sebagai Menteri Sekretaris Negara yang didakwa korupsi karena mengutungkan diri sendiri atau orang lain atau suatu badan dengan menyalahgunakan kewenangannya yaitu mengeluarkan kebijakan pembelian dan pengadaan sembako bagi masyarakat miskin, akan tetapi telah merugikan keuangan negara. Dalam hal ini Ir. Akbar Tanjung didakwa oleh penuntut umum dalam sidang pengadilan, baik di tingkat pertama, banding maupun kasasi, telah menerima dan menggunakan uang Badan Urusan Logistik (BULOG) sebesar Rp. 40.000.000.000,- (empat

\footnotetext{
${ }^{18}$ Lihat juga Suwoto, 1990, “Kekuasaan dan Tanggung Jawab Presiden Republik Indonesia”, Disertasi, Universitas Airlangga, Surabaya, h. 154 dan 156.

${ }^{19}$ Satjipto Rahardjo, 2009, Negara Hukum yang Membahagiakan Rakyatnya, Yogyakarta: Penerbit Genta Publishing, h. 93 .
} 
puluh miliar rupiah) untuk kepentingan pembelian dan pengadaan sembako bagi masyarakat miskin. Alasan dakwaan karena tindakan tersebut tidak sesuai dengan ketentuan yang berlaku dan di luar kepentingan dan tugas BULOG, serta menyalahi ketentuan yang berlaku dalam tata cara penggunaan uang negara. ${ }^{20}$

Selanjutnya pada masa pemerintahan Presiden Soesilo Bambang Yudhoyono, timbul polemik mengenai kebijakan Hatta Radjasa selaku Menteri Koordinator Perekonomian untuk mengimpor minyak. Kebijakannya dinilai menimbulkan korupsi karena hanya menguntungkan segelintir kelompok orang sebagai mafia minyak yang diduga merugikan negara Rp. 100 000.000.000,- (seratus miliar rupiah)/hari atau 36 triliun rupiah/tahun. Keuntungan para mafia minyak atas kebijakannya tersebut mengakibatkan subsidi Anggaran Pendapatan Belanja Negara terus membengkak dan utang negara semakin bertambah tinggi, sehingga pada akhirnya mengorbankan kepentingan rakyat ${ }^{21}$.

Apabila dihubungkan secara yuridis dengan ketentuan Pasal 8 ayat (1) huruf a, ayat (2) huruf a, dan ayat (3) huruf a Undang-Undang Nomor 39 Tahun 2008 tentang Kementerian Negara, maka kementerian menyelenggarakan fungsi yaitu perumusan, penetapan, dan pelaksanaan kebijakan di bidangnya. Apabila ketentuan tersebut ditafsir secara gramatikal ${ }^{22}$, maka kewenangan menteri mengeluarkan kebijakan adalah kewenangan mandiri sehingga menteri yang sepenuhnya bertanggung jawab atas kebijakannya.

Akan tetapi, jika dirunut secara original intent dan tafsir ekstensif ${ }^{23}$ dari Pasal 17 UUD NRI Tahun 1945, dan kemudian dihubungkan secara teoritik dengan makna dan konsep mandat, maka kewenangan menteri mengeluarkan kebijakan bukanlah kewenangan yang bersifat mandiri, melainkan kewenangan mandat. Dalam kasus kebijakan Ir. Akbar Tanjung misalnya, responsibility administrasi negara ada pada Presiden. Hal ini diketahui dari adanya petunjuk atau disposisi atau persetujuan Presiden kepada Ir. Akbar Tanjung selaku Menteri Sekretaris Negara untuk mengeluarkan kebijakan tentang penggunaan dana non budgeter sebesar Rp. 40.000.000.000,- (empat puluh miliar rupiah) dalam rangka pembelian dan pengadaan sembako bagi masyarakat miskin.

Kemudian pada kasus Hatta Radjasa, apabila dihubungkan dengan Pasal 4 ayat (2) huruf c Undang-Undang Nomor 39 Tahun 2008 tentang Kementerian Negara, maka fungsi Menteri Koordinator antara lain koordinasi dan sinkronisasi program pemerintah dengan kementerian lainnya. Oleh karenanya tugas Menteri Koordinator Perekonomian bukanlah mengeluarkan kebijakan mengimpor minyak. Dengan demikian, kebijakan Menteri Koordinator Perekonomian untuk mengimpor minyak sudah tentu atas persetujuan Presiden. Secara

${ }^{20}$ Lihat Putusan Pengadilan Negeri Jakarta Pusat Nomor: 449/PID.B/2002/PN.JKT.PST, Putusan Pengadilan Tinggi DKI Jakarta Nomor 171/Pid/2002/PT.DKI, dan Putusan Mahkamah Agung RI, Reg. No. 572/Pid/2003.

${ }^{21}$ www.beritasatu.com.

22 Tafsir gramatikal adalah menafsirkan kata-kata dalam peraturan perundang-undangan sesuai kaidah tata bahasa.

${ }^{23}$ Tafsir ekstensif adalah penfsiran yang memperluas suatu makna hukum atau melebihi batas-batas tafsiran gramatikal. 
teoritik, kewenangan Hatta Radjasa mengeluarkan kebijakan mengimpor minyak merupakan kewenangan mandat yaitu kewenangan untuk dan atas nama Presiden.

Berdasarkan kewenangan mandat, maka berlaku azas vicarious liability yaitu atasanlah yang bertanggung jawab, artinya Presidenlah yang bertanggung jawab secara hukum atas kebijakan yang dikeluarkan oleh menterinya termasuk yang menimbulkan korupsi. Hubungan mandat antara Presiden dan menteri dicirikan oleh: pertama, perintah untuk melaksanakan tugas dan kewenangan tertentu dari atasan oleh bawahan; kedua, kewenangan yang dijalankan oleh bawahan itu dapat sewaktu-waktu dilaksanakan oleh pemberi mandat (mandas atau atasan); ketiga, tidak terjadi peralihan tanggung jawab; keempat, pelaksanaan kewenangan tidak harus berdasarkan undang-undang; dan kelima, perintah pelaksanaan kewenangan itu dapat tertulis dan dapat pula secara lisan. ${ }^{24}$

\section{PENUTUP}

a. Berdasarkan sistem pemerintahan presidensial yang dianut oleh UUD NRI Tahun 1945, menteri adalah pembantu presiden yang diangkat dan diberhentikan oleh Presiden. Dengan konstruksi kabinet presidensial tersebut, mengakibatkan Presiden bertanggung jawab secara moral dan politik atas kebijakan menteri yang menimbulkan korupsi. Presiden bertanggung jawab secara moral kepada rakyat apabila menteri mengeluarkan kebijakan yang melanggar nilai moral. Selanjutnya, Presiden bertanggung jawab secara politik kepada rakyat: (a) apabila menteri mengeluarkan kebijakan yang melanggar peraturan perundang-undangan, dan (b) apabila dari hasil temuan BPK terdapat kebijakan menteri yang menimbulkan kerugikan keuangan negara.

b. Berdasarkan teori kewenangan terdapat tiga jenis kewenangan yaitu atribusi, delegasi, dan mandat. Presiden adalah pemberi mandat dan menteri sebagai mandataris sehingga berlaku azas vicarious liability yaitu atasanlah yang bertanggung jawab. Hal ini artinya Presiden bertanggung jawab secara hukum atas kebijakan menteri yang menimbulkan korupsi.

\section{DAFTAR PUSTAKA}

\section{A. Buku}

Algra, N.E. \& H.C.J.G. Janssen. 1974. Rechtsingang, een Orientatie in het Recht. H.D.Tjeenk Willink bv: Groningen.

Asshiddiqie, Jimly. 2007. Pokok-Pokok Hukum Tata Negara Pasca Reformasi. Jakarta: Penerbit Bhuana Ilmu Populer.

\footnotetext{
${ }^{24}$ Ridwan, Dimensi Hukum Kewenangan Pemerintah dan Pertanggungjawabannya, Artikel dalam Akuntabilitas Putusan Akbar Tanjung oleh Mahkamah Agung, Yogyakarta, Penerbit:Universitas Islam Indonesia Press, h. 586.
} 


\section{KERTHA PATRIKA}

Volume 39, Nomor 2, Agustus 2017

Dworkin, Ronal. 1996. Freedom's Law, The Moral Reading of American Constitution. Cambridge: Penerbit Mass Harvard University.

Indrayana, Denny. 2007. Amandemen UUD 1945: Antara Mitos dan Pembongkaran. Jakarta: Penerbit Mizan.

Isra, Saldi.2010. Pergeseran Fungsi Legislasi. Jakarta: Penerbit Raja Grafindo.

Logemann. 1954. Over de Theorie van een Stellig Staatsrecht. Jakarta: Penerbit Seksama.

Rahardjo, Satjipto. 2009. Negara Hukum yang Membahagiakan Rakyatnya. Yogyakarta: Penerbit Genta Publishing.

Saputra, M, Nata.1988. Hukum Administrasi Negara. Jakarta: Penerbit Rajawali.

Ridwan. Dimensi Hukum Kewenangan Pemerintah dan Pertanggungjawabannya. Akuntabilitas Putusan Akbar Tanjung oleh Mahkamah Agung. Yogyakarta: Penerbit Universitas Islam Indonesia Press.

Termorshuizen, Marjanne. 2002. Kamus Hukum Belanda-Indonesia. Jakarta: Penerbit Djambatan.

\section{B. Disertasi/Makalah}

Lukman, Marcus. 1996. "Eksistensi Peraturan Kebijaksanaan dalam Bidang Perencanaan dan Pelaksanaan Rencana Pembangunan di Daerah serta Dampaknya terhadap Pembangunan Materi Hukum Tertulis Nasional”. Disertasi. Universitas Padjajaran, Bandung.

Marzuki, Laica. 26-31 Agustus 1996. "Peraturan Kebijaksanaan (Beleidsregel) Hakikat serta Fungsinya Selaku Sarana Hukum Pemerintahan". Makalah pada Penataran Nasional Hukum Acara dan Hukum Administrasi Negara. Fakultas Hukum Universitas Hasanudin. Ujung Pandang.

Philips A. Kana. 2006. "Para Menteri Tidak Bisa Lepas Tanggung Jawab". Makalah. Universitas Krisna Dwipayana.

Suwoto. 1990. "Kekuasaan dan Tanggung Jawab Presiden Republik Indonesia”. Disertasi. Universitas Airlangga, Surabaya.

\section{Internet}

http://www.beritasatu.com

\section{Peraturan Perundang-Undangan}

Undang-Undang Dasar Negara Republik Indonesia Tahun 1945 
Undang-Undang Nomor 39 Tahun 2008 tentang Kementerian Negara (Lembaran Negara Tahun 2008 Nomor 166 Tambahan Lembaran Negara Nomor 4916)

\section{E. Putusan Pengadilan}

Putusan Mahkamah Agung RI, Reg. No. 572/Pid/2003

Putusan Pengadilan Negeri Jakarta Pusat Nomor: 449/PID.B/2002/PN.JKT.PST

Putusan Pengadilan Tinggi DKI Jakarta Nomor 171/Pid/2002 